Rev. Fac. Agron. (LUZ). 2021, 38: 84-104. Enero-Marzo.

DOI: https://doi.org/10.47280/RevFacAgron(LUZ).v38.n1.05

ISSN 2477-9407

\title{
Effect of duckweed meal dietary inclusion on growth performance and survival of African catfish fingerlings
}

Efecto de la inclusión de harina de lenteja de agua en dieta sobre el crecimiento y la supervivencia de los alevines de bagre Africano

Efeito da inclusão de farinha de lentilha d'água na dieta sobre o crescimento e sobrevivência de alevinos de bagre Africano

\section{Yuniel Méndez-Martínez ${ }^{1 *}$, Yenny G. Torres Navarrete ${ }^{1}$, Yilian Pérez Tamames², Misleidi Romás Viltres², Edilmar Cortés-Jacinto ${ }^{3}$}

${ }^{1}$ Facultad de Ciencias Pecuarias, Universidad Técnica Estatal de Quevedo (UTEQ), Quevedo, Los Ríos, Ecuador. Correos electrónicos: (YMM) ymendezmartinez@gmail.com, (D; (YGTN) ytorres@uteq.edu.ec,(Đ. ${ }^{2}$ Facultad de Ciencias Agropecuarias, Universidad de Granma (UDG), Bayamo, Granma, Cuba. Correos electrónicos: (YPT) ypereztamames@gmail.com, (1D; (MRV) romasviltresm@gmail.com, (i); ${ }^{3}$ Programa de Acuicultura, Centro de Investigaciones Biológicas del Noroeste, S.C. (CIBNOR), La Paz, B.C.S., México. Correo electrónico: ecortes04@cibnor.mx, (iD.

\section{Abstract}

Currently, the use of unconventional food sources in the inclusion of fish diets is cause of great interest. The growth performance of African catfish (Clarias gariepinus) was evaluated, with the inclusion of duckweed meal (Lemna perpusilla) in four levels $(0,6,12$ and $18 \%)$ in the diet. African catfish with an average weight of $1.27 \pm 0.03 \mathrm{~g}$, were distributed in a completely randomized design, with 16 experimental cages (four replicates/treatment). The fingerlings were fed for 48 days of experimentation. An analysis of variance and a Duncan's test were performed. No significant differences were found $(p<0.05)$ for the first two levels evaluated, but with the rest there were differences, as the percentage of inclusion of the duckweed meal in the ration increased. Final weight was decreasing, as

Recibido el 11-08-2020 • Aceptado el 29-09-2020.

*Autor de correspondencia. Correo electrónico: ymendezmartinez@gmail.com 
Rev. Fac. Agron. (LUZ). 2021, 38: 84-104. Enero-Marzo.

Méndez-Martínez et al.

well as absolute growth rate, increase in daily weight, feed conversion ratio and food efficiency. Survival throughout the experiment was between 72 y $65 \%$ in all treatments. The inclusion of duckweed meal in the diet did not affect the parameters of water quality. It was concluded that the $L$. perpusillase meal can be included up to $12 \%$ in diets for African catfish fingerlings, without affecting the growth performance.

Keywords: aquatic plants, Clarias gariepinus, Lemna perpusilla, pelleted feed, weight gain.

\section{Resumen}

El uso de alimentos no convencionales en las dietas para peces es actualmente de gran interés. Se evaluó el comportamiento productivo de alevines de bagre africano (Clarias gariepinus), con la inclusión de la harina de la lenteja de agua (Lemna perpusilla) en cuatro niveles $(0,6,12$ y $18 \%$ ) en la formulación de la dieta. Se utilizaron 240 animales, con un peso promedio de 1,27 $\pm 0,03 \mathrm{~g}$, distribuidos en un diseño completamente al azar, con 15 por réplicas (cuatro réplicas/tratamiento). Se realizó un análisis de varianza y una prueba de medias por Duncan. Los alevines fueron alimentados durante 48 días, no se encontraron diferencias significativas $(\mathrm{p}<0,05)$ para los dos primeros niveles evaluados, y si con los restantes, en la medida que aumentaba el porcentaje de inclusión de harina de la lenteja de agua en la ración. El peso final fue descendiendo, así como el crecimiento absoluto, incremento en peso diario, factor de conversión alimenticia y eficiencia alimentaria. La supervivencia durante todo el experimento estuvo entre 72 y $65 \%$. La inclusión de este alimento en la dieta no afectó los parámetros de calidad del agua. Se concluyó que la harina de $L$. perpusilla se puede incluir hasta $12 \%$ en dietas para alevines de bagre africano, sin afectar los indicadores bio-productivos.

Palabras claves: alimento peletizado, Clarias gariepinus, ganancia de peso, Lemna perpusilla, plantas acuáticas.

\section{Resumo}

O uso de insumos alimentares não convencionais na inclusão de dietas para peixes é atualmente de grande interesse. Foi avaliado o comportamento produtivo de alevinos de jundiá (Clarias gariepinus), com a inclusão de farinha de lentilhad'água (Lemna perpusilla) em quatro níveis $(0,6,12$ e $18 \%)$ na formulação da dieta. Foram utilizados 240 animais, com peso médio de $1.27 \pm 0.03 \mathrm{~g}$, distribuídos em delineamento inteiramente casualizado, com 15 por repetições (quatro repetições/tratamento). Foi realizada uma análise de variância e um teste de médias de Duncan. Aos 48 dias de cultivo experimental, não foram encontradas diferenças significativas $(\mathrm{p}<0.05)$ para os dois primeiros níveis avaliados, e se com os demais, conforme aumentou a porcentagem de inclusão de farinha de lentilha- 
d'água na ração. O peso final foi diminuindo, assim como o crescimento absoluto, aumento do peso diário, fator de conversão alimentar e eficiência alimentar. A sobrevivência durante todo o experimento foi entre 72 e $65 \%$. A inclusão desse alimento na dieta não afetou os parâmetros de qualidade da água. Concluiu-se que o farelo de $L$. perpusilla pode ser incluído em até $12 \%$ em dietas para alevinos bagrefrenses, sem afetar os indicadores de bioprodução.

Palavras chaves: Clarias gariepinus, ganho de peso, Lemna perpusilla, plantas aquáticas, ração peletizada.

\section{Introduction}

Worldwide food production from aquaculture has had an average annual $6.7 \%$, increase with yields higher than 90.4 million tons (FAO, 2020). Feed remains one of important factors in fingerling cultivation. Nutritional composition of feed given during fingerling rearing has a significant influence to the fish growth in the following phases. Feeding cost in fish farming is about $50 \%$ of the total production cost of the fish (Mambrini, and Guillaume, 2011; Méndez-Martínez et al., 2017). Reducing fish meal is an important issue in the aquaculture industry because of its increased price (Lim and Lee, 2011; Putra et al., 2017). Replacing the amount of fish meal in diet formulation with alternative local feed material is one of solutions (Kader et al., 2013).

Fish feed components on one hand are suggested to be more affordable and not causing competition to human consumption needs, while in the other hand have to contain sufficient good quality nutrients for fish growth, which is defined as the increasing size, weight, and length in a certain time. Growth occurs when there is

\section{Introducción}

La producción mundial de alimentos provenientes de la acuicultura ha tenido un incremento promedio anual de $6,7 \%$, con rendimientos superiores a 90,4 millones de toneladas (FAO, 2020). La alimentación sigue siendo uno de los factores importantes en el cultivo de alevines y la composición nutricional del alimento administrado durante la cría de alevines tiene una influencia significativa en el crecimiento de los peces en las siguientes fases. El costo de alimentación en la piscicultura constituye aproximadamente el $50 \%$ del costo total de producción de los peces (Mambrini y Guillaume, 2011; Méndez-Martínez et al., 2017). La reducción de la harina de pescado es un tema importante en la industria de la acuicultura debido a su aumento de precio (Lim y Lee, 2011; Putra et al., 2017). Reemplazar la cantidad de harina de pescado en la formulación de la dieta con material alimenticio local alternativo es una de las soluciones (Kader et al., 2013).

Se ha sugerido que los componentes del alimento para peces, por un lado, sean más asequibles y no causen competencia a las necesidades para el 
Rev. Fac. Agron. (LUZ). 2021, 38: 84-104. Enero-Marzo.

the surplus input of energy and amino acids derived from feed. Acquired energy is used for basic metabolic maintenance (i.e. respiration, specific, and dynamic action), excreted out of the body, or available as surplus energy. This excess energy afterward is allocated for gaining weight (somatic growth), gonadal maturation and reproduction, or being stored in muscle, liver, and mesenteric fat (McBride et al., 2015; Herawati et al., 2020).

The aquaculture development is based on the implementation of technologies for the production of balanced feed, genetic improvement and the introduction of new species, among which are the common carp (Cyprinus carpio), red Tilapia (Oreochromis spp.) and African catfish (Clarias gariepinus) (FAO, 2020).

Currently thelatter it is considered of vital importance due to the texture of its meat, its nutritive contribution, high growth rate, fecundity, and larger size. The African catfish is one of the most important freshwater aquaculture fish, the popular species for aquaculture business in Southeast Asian countries (Putra et al., 2017). This specie is an opportunistic and omnivorous feeder ingesting a wide variety of food items such as algae, macrophytes, zooplankton, insects, fish prey, detritus, Amphibians and sand grains (Dadebo et al., 2014; Admasu et al., 2015). The diet composition may vary within season and spatial conditions of the environments (Houlihan et al., 2001). In the same way, the diet composition may also vary depends consumo humano, mientras que, por otro lado, deben contener suficientes nutrientes de buena calidad para el crecimiento de los peces, lo que se define como el aumento de tamaño, peso y longitud en un tiempo determinado. El crecimiento se produce cuando existe un aporte excedente de energía y aminoácidos del alimento. La energía adquirida se utiliza para el mantenimiento metabólico básico (es decir, respiración, acción específica y dinámica), se excreta fuera del cuerpo o se encuentra disponible como energía excedente. Este exceso de energía luego se asigna para ganar peso (crecimiento somático), maduración y reproducción gonadal, o almacenarse en el músculo, hígado y grasa mesentérica (McBride et al., 2015; Herawati et al., 2020).

El desarrollo de la acuicultura se basa en la implementación de tecnologías para la producción de alimento balanceado, mejoramiento genético y la introducción de nuevas especies, entre las que se encuentran la carpa común (Cyprinus carpio), la Tilapia roja (Oreochromis spp.) y el bagre africano (Clarias gariepinus) (FAO, 2020).

Actualmente a este último se le considera de vital importancia para la textura de su carne, su aporte nutritivo, alta tasa de crecimiento, fecundidad y mayor tamaño. El bagre africano es uno de los peces de acuicultura de agua dulce más importantes, especie popular para el negocio de la acuicultura en los países del sudeste asiático (Putra et al., 2017). Esta especie es un alimentador oportunista y omnívoro que ingiere una amplia 
upon the fish size, maturity, and habitat differences (da Silva et al., 2014; Herawati et al., 2020). Several authors have studied the feeding and eating habits of African catfish in water bodies, noting that this specie feeds on a variety of foods based on the environment in which it lives (Admasu et al., 2015; Dadebo et al., 2014; Putra et al., 2017).

What makes it possible, the use of unconventional foods in the diet. Among which we can highlight the small floating aquatic plants, such as duckweed (Uddin et al., 2007; Talukdar et al., 2012). This plant may benefit for the aquaculture business as a cheap and abundant source of feed ingredient (Flores-Miranda et al., 2015; Sirakov and Velichkova, 2018 ), given that its ability to grow rapidly on water bodies. Ansal et al., (2010) reported that the productivity of duckweeds, planted in an effective planting system reach to $12-38$ tons of dry weight.ha-1.year ${ }^{-1}$. Lemna is a potential source of nutrients as crude protein (28-43\%), minerals, vitamins, beta-carotene and vitamin B12 (Islami, 2002).

The L. perpusilla meal could be used as a local alternative in aquaculture species feed, especially in diets for African catfish, due to its high protein value, its low cost as unconventional feed, in addition to meeting the high requirements of this species. To determine the biological response of African catfish fingerlings (C. gariepinus), by including different levels of $L$. perpusilla meal in the diet was objective of this work. variedad de alimentos como algas, macrófitos, zooplancton, insectos, presas de peces, detritos, anfibios y granos de arena (Dadebo et al., 2014; Admasu et al., 2015). La composición de su dieta puede variar dentro de la temporada y las condiciones espaciales de los ambientes (Houlihan et al., 2001). Así mismo, la composición de la dieta puede variar dependiendo del tamaño de los peces, la madurez y las diferencias de hábitat (da Silva et al., 2014; Herawati et al., 2020). Varios autores han estudiado los hábitos alimentarios y alimenticios del bagre africano en cuerpos de agua, señalando que esta especie se alimenta de una variedad de alimentos en función del entorno en el que vive (Admasu et al., 2015; Dadebo et al., 2014; Putra et al., 2017).

Esto es posible debido al uso de alimentos no convencionales en la dieta, entre las que se pueden destacar las pequeñas plantas acuáticas flotantes, como la lenteja de agua (Uddin et al., 2007; Talukdar et al., 2012). Esta planta puede beneficiarse para el negocio de la acuicultura como una fuente abundante y barata de ingrediente alimentario (FloresMiranda et al., 2015; Sirakov y Velichkova, 2018), dada su capacidad para crecer rápidamente en cuerpos de agua. Ansal et al. (2010) reportaron que la productividad de la lenteja de agua, plantada en un sistema de siembra eficaz, alcanza entre 12 y 38 toneladas de peso seco.ha-1.año ${ }^{-1}$. La Lemna es una fuente potencial de nutrients, como proteína cruda (28-43\%), minerales, vitaminas, betacaroteno y vitamina B12 (Islami, 2002). 
Rev. Fac. Agron. (LUZ). 2021, 38: 84-104. Enero-Marzo.

Méndez-Martínez et al.

\section{Materials and methods}

\section{Experimental design and setup}

Experiment was carried out in UEB "René Ramos", Granma, Cuba. Were used 240 animals, with an average weight of $1.27 \pm 0.03 \mathrm{~g}$, distributed in a completely randomized design. They were sown in cages inside a concrete pond $\left(20 \mathrm{~m}^{2}\right)$, with 16 experimental cages $(1.75 \times 0.76 \times 0.80 \mathrm{~m}$ long, wide and high respectively, resulting in a total volume of $1.06 \mathrm{~m}^{3}$ ), for four replicates/ treatment. Previously washed with chlorine solution at a concentration of $100 \mathrm{ppm}$ and washed with abundant water. African catfish were acclimated to experimental conditions for one week to reduce stress. The experiment culture was for 48 days. Estimated daily water replacement in the pond was about 20 $\%$. The fishes were fed twice daily in two rations at 09:00 $\mathrm{h}$ and 17:00 $\mathrm{h}$.

Water quality parameters such as temperature and dissolved oxygen were measured daily with a digital multi-parameter probe (Model 55, YSI, Yellow Springs, $\mathrm{OH}$ ); $\mathrm{pH}$ was measured daily with a $\mathrm{pH}$ meter (American Marine, Ridgefield, CT); and total ammonium was determined weekly with a portable spectrophotometer (Hach DREL 2800, Loveland, CO). The photoperiod was $12 \mathrm{~h}$ light-12 $\mathrm{h}$ darkness, which is normal for the season. The feeding was ad libitum, which in turn guarantees adequate growth without dietary restrictions and intake was determined by feeding to apparent satiation a similar protocol as described by Méndez-Martínez et al. (2017).
La harina de L. perpusilla podría utilizarse como alternativa local en la alimentación de especies acuícolas, especialmente en dietas para bagre africano, debido a su alto valor proteico, su bajo costo como alimento no convencional, además de cumplir con los altos requerimientos de esta especie. Determinar la respuesta biológica de los alevines de bagre africano (C. gariepinus), mediante la inclusión de diferentes niveles de harina de $L$. perpusilla en la dieta fue objetivo de este trabajo.

\section{Materiales y métodos}

\section{Diseño experimental y montaje}

El experimento se realizó en la UEB "René Ramos", Granma, Cuba. Se utilizaron 240 animales con un peso promedio de 1,27 $\pm 0,03 \mathrm{~g}$, distribuidos en un diseño completamente al azar. Se sembraron en jaulas dentro de un estanque de hormigón $\left(20 \mathrm{~m}^{2}\right)$, con 16 jaulas experimentales $(1,75 \times 0,76 \times 0,80$ $\mathrm{m}$ de largo, ancho y alto respectivamente, resultando en un volumen total de 1,06 $\mathrm{m}^{3}$ ), para cuatro repeticiones/tratamiento. Previamente lavados con solución de cloro a una concentración de 100 ppm y luego abundante agua corriente. Los bagres africanos se aclimataron a las condiciones experimentales durante una semana para reducir el estrés. El cultivo experimental fue de 48 días. El reemplazo de agua diario estimado en el estanque fue de aproximadamente el $20 \%$. Los peces fueron alimentados dos veces al día en dos raciones a las 09:00 h y 17:00 h.

Los parámetros de calidad del agua, como la temperatura y el oxígeno 
Experimental diets. All diets were formulated using the Excel Solver of Windows 2010, to contain four levels of inclusion of $L$. perpusilla meal at 0,6 , 12 and $18 \%$ (table 1). All ingredients were sieved through a $250-\mu \mathrm{m}$ mesh, and each diet was prepared by mixing all the macro-ingredients in an industrial blender until a uniform mixture was obtained. The micro-ingredients and soy lecithin were mixed by hand in a plastic container until obtaining a homogeneous blend, before adding them to the macroingredients, and then water was added with an equivalent of $30 \%$ per weight of the ingredients. 2-mm pellets were extruded with a meat grinder and dried during $8 \mathrm{~h}$ at $45^{\circ} \mathrm{C}$ in an air flux oven. Thereafter, dried pellets were packed in plastic bags and kept refrigerated at $-4^{\circ} \mathrm{C}$ until its use as suggested by MéndezMartínez et al. (2017; 2018).

Cultivation of the $L$. perpusilla and meal manufacture: For the cultivation was planted 25 g.m . $^{2}$ in two concrete (Caicedo et al., 2000), pools with a dimension of 200 $\mathrm{m}^{2}$ each, for a total area of $400 \mathrm{~m}^{2}$. The duckweed was collected manually when the plants covered the entire surface of the two pools. The collection was made at six-day intervals. The fresh biomass harvested was carefully washed, later sun dried $\left(33-35^{\circ} \mathrm{C}\right)$ during two days $(8$ h.day ${ }^{-1}$ ) on a polyethylene mat, to facilitate drying, according the methodology of Fasakin et al. (2001), and was milled to a particle size of $2 \mathrm{~mm}$ using a laboratory milland and was sieved through a $250-\mu \mathrm{m}$ mesh, and later it was stored in air-tight polyethylene bags and were preserved at $-4^{\circ} \mathrm{C}$ in a refrigerator prior to use as suggested by Méndez-Martínez et al. (2017; 2018). disuelto, se midieron diariamente con una sonda digital multiparámetro (Modelo 55, YSI, Yellow Springs, $\mathrm{OH})$; El $\mathrm{pH}$ se midió diariamente con un medidor de $\mathrm{pH}$ (American Marine, Ridgefield, CT); y el amonio total se determinó semanalmente con un espectrofotómetro portátil (Hach DREL 2800, Loveland, CO). El fotoperiodo fue de $12 \mathrm{~h}$ de luz - $12 \mathrm{~h}$ de oscuridad, lo que es normal para la temporada. La alimentación fue $a d$ libitum, lo que a su vez garantiza un crecimiento adecuado sin restricciones dietéticas y la ingesta se determinó alimentando hasta saciedad aparente, protocolo similar al descrito por Méndez-Martínez et al. (2017).

Dietas experimentales. Todas las dietas se formularon utilizando Excel Solver de Windows 2010, para contener cuatro niveles de inclusión de harina de L. perpusilla al 0, 6, 12 y $18 \%$ (cuadro 1). Todos los ingredientes se tamizaron a través de una malla de $250 \mu \mathrm{m}$ y cada dieta se preparó mezclando todos los macroingredientes en una licuadora industrial hasta que se obtuvo una mezcla uniforme. Los microingredientes y la lecitina de soja se mezclaron a mano en un recipiente de plástico hasta obtener una mezcla homogénea, antes de agregarlos a los macroingredientes, $\mathrm{y}$ luego se agregó agua con un equivalente al $30 \%$ por peso de los ingredientes. Se extruyeron gránulos de $2 \mathrm{~mm}$ con una picadora de carne y se secaron durante $8 \mathrm{~h}$ a $45^{\circ} \mathrm{C}$ en un horno de flujo de aire. Posteriormente, los gránulos secos se empacaron en bolsas plásticas y se mantuvieron refrigerados a $-4^{\circ} \mathrm{C}$ hasta su uso como lo sugiere MéndezMartínez et al. (2017; 2018). 
Rev. Fac. Agron. (LUZ). 2021, 38: 84-104. Enero-Marzo.

Table 1. Formulation, proximate composition and essential amino acids of four experimental diets (\% in dry matter) for Clarias gariepinus fingerlings.

\section{Cuadro1. Formulación, composición proximal, y aminoácidos esenciales de cuatro dietas experimentales (\% en materia seca) para alevines de Clarias gariepinus.}

\begin{tabular}{|c|c|c|c|c|}
\hline \multirow[t]{2}{*}{ Ingredient (\%) } & \multicolumn{4}{|c|}{ Lemna perpusilla meal (\%) } \\
\hline & 0 & 6 & 12 & 18 \\
\hline Fish meal & 47 & 46 & 45 & 44 \\
\hline Corn meal & 26 & 21 & 15 & 10 \\
\hline Rice Bran & 20 & 20 & 21 & 21 \\
\hline Lemna perpusilla meal & 0 & 6 & 12 & 18 \\
\hline Alginate & 2 & 2 & 2 & 2 \\
\hline Mineral Premix ${ }^{1}$ & 0.70 & 0.70 & 0.70 & 0.70 \\
\hline Vitamin Premix ${ }^{2}$ & 0.30 & 0.30 & 0.30 & 0.30 \\
\hline Dicalcium phosphate & 2 & 2 & 2 & 2 \\
\hline Soy Lecithin & 2 & 2 & 2 & 2 \\
\hline \multicolumn{5}{|l|}{ Proximate composition } \\
\hline Dry matter (\%) & 88.83 & 89.05 & 89.30 & 89.52 \\
\hline Crude protein (\%) & 35.23 & 35.81 & 36.44 & 37.03 \\
\hline Crude Fiber (\%) & 3.15 & 3.46 & 3.86 & 4.17 \\
\hline Ether extract (\%) & 3.48 & 3.48 & 3.91 & 3.53 \\
\hline Nitrogen Free Extract ${ }^{3}$ & 46.54 & 44.55 & 41.88 & 40.26 \\
\hline Ashes $(\%)$ & 11.60 & 12.70 & 13.91 & 15.01 \\
\hline Gross energy (MJ.kg $\left.{ }^{-1}\right)$ & 20.47 & 21.57 & 22.96 & 24.06 \\
\hline \multicolumn{5}{|c|}{ Essential amino acids (protein level, \%) } \\
\hline Threonine & 1.37 & 1.54 & 1.71 & 1.87 \\
\hline Valina & 1.77 & 2.01 & 2.25 & 2.49 \\
\hline Methionine & 0.91 & 0.97 & 1.04 & 1.10 \\
\hline Isoleucine & 1.41 & 1.63 & 1.84 & 2.05 \\
\hline Leucine & 2.76 & 3.02 & 3.29 & 3.56 \\
\hline Lysine & 2.41 & 2.50 & 2.60 & 2.69 \\
\hline Histidine & 0.78 & 0.84 & 0.89 & 0.94 \\
\hline Arginine & 2.03 & 2.15 & 2.26 & 2.38 \\
\hline Tryptophan & 0.36 & 0.60 & 0.84 & 1.08 \\
\hline Phenylalanine & 1.34 & 1.52 & 1.68 & 1.85 \\
\hline
\end{tabular}

${ }^{1} \mathrm{mg.kg}^{-1}$ : Magnesium Sulfate 5.1; Sodium Chloride 2.4; Potassium Chloride 2; Ferrous Sulfate 1; Zinc Sulfate 0.2; Cupric sulfate 0.0314; Manganous sulfate 0.1015; Cobalt sulfate 0.0191; Calcium iodate 0.0118; Chlorine chloride 0.051. ${ }^{2} \mathrm{mg} \mathrm{kg}^{1}$ : Thiamin 60; Rivoflavin 25; Niacin 40; Vitamin B6 50; Pantothenic Acid 75; Biotin 1; Folate 10; Vitamin B12 0.2; Hill 600; Myoinositol 400; Vitamin C 200; Vitamin A 5000 IU; Vitamin E 100; Vitamin D 0.1; Vitamin K 5. ${ }^{1}$ Data are expressed as mean \pm SD of three replicates. ${ }^{3}$ Nitrogen free extract $=100-(\%$ crude protein $+\%$ ether extract $+\%$ crude fiber $+\%$ ash).

${ }^{1}$ mg.kg-1: Sulfato de magnesio 5.1; Cloruro de sodio 2,4; Cloruro de potasio 2; Sulfato ferroso 1; Sulfato de zinc 0,2; Sulfato cúprico 0,0314; Sulfato manganoso 0,1015; Sulfato de cobalto 0,0191; Yodato de calcio 0,0118; Cloruro de cloro 0.051. ${ }^{2} \mathrm{mg} \cdot \mathrm{kg}^{-1}$ : tiamina 60; Rivoflavina 25; Niacina 40; Vitamina B6 50; Ácido pantoténico 75; Biotina 1; Folato 10; Vitamina B12 0,2; Hill 600; Myoinositol 400; Vitamina C 200; Vitamina A 5000 UI; Vitamina E 100; Vitamina D 0,1; Vitamina K 5. ${ }^{1}$ Los datos se expresan como media \pm DE de tres repeticiones. ${ }^{3}$ Extracto libre de nitrógeno $=100-(\%$ proteína bruta $+\%$ extracto etéreo $+\%$ fibra bruta $+\%$ ceniza $)$. 
Rev. Fac. Agron. (LUZ). 2021, 38: 84-104. Enero-Marzo.

\section{Proximate composition and} amino acid profile in diets. The analysis of proximate composition including dry matter, crude protein, ash, crude fiber, ether extract and nitrogen free extract were determined in agreement with AOAC (2019). Gross energy of the diets was calculated based on conversion factors of $16.7 \mathrm{~kJ} . \mathrm{g}^{-1}$ protein and carbohydrate, and $37.6 \mathrm{~kJ} . \mathrm{g}^{-1}$ lipid (Cuzon and Guillaume, 1997; NRC, 2011). Amino acid profiles were also made in triplicate after the diets were lyophilized and defatted. These samples were analyzed by high performance liquid chromatography (Agilent 1100- HPLC, Pleasanton, CA) (Umagat et al., 1982).

Evaluation of growth and production rates. The fish were individually weighed on a digital balance $( \pm 0.01 \mathrm{~g}$; PE 3600 MettlerToledo, Columbus, OH, USA), and the total length was determined with a digital vernier caliper $( \pm 0.001$ mm, GT-MA15 Gester, Xiamen, CHN). All calculations were obtained from average of four replicates. The following formulae were applied to obtain production and nutritional parameters.

Weight gain $(\mathrm{WG}, \mathrm{g})=W x-W i$,

Lenght gain $(\mathrm{LG}, \mathrm{g})=L x-L i$,

Day average weight gain (DAW, g) $\mathrm{DAW}=(W x-W i) / t$,

Day average lenght gain (DAL, g) $\mathrm{DAL}=(L x-L i) / t$,

Specific growth rate (SGR) = $[(\ln W x-\ln W i)] / t \times 100$,

Feed conversion ratio $(\mathrm{FCR})=$ total feed consumed (g) / total weight gain (g, wet weight),
Cultivo de L. perpusilla y elaboración de harinas. Para el cultivo se sembraron 25 g.m ${ }^{2}$ en dos piscinas de concreto (Caicedo et al., 2000) con una dimensión de $200 \mathrm{~m}^{2}$ cada una, para un área total de $400 \mathrm{~m}^{2}$. La lenteja de agua se colectó manualmente cuando las plantas cubrieron toda la superficie de las dos piscinas. La recolección se realizó a intervalos de seis días. La biomasa fresca recolectada se lavó cuidadosamente, luego se secó al sol $\left(33-35{ }^{\circ} \mathrm{C}\right)$ durante dos días $(8$ h.día $\left.{ }^{-1}\right)$ sobre una estera de polietileno, para facilitar el secado, según la metodología de Fasakin et al. (2001) y se molió a un tamaño de partícula de $2 \mathrm{~mm}$ utilizando un molino de laboratorio y se tamizó a través de una malla de $250 \mu \mathrm{m}$, y luego se almacenó en bolsas de polietileno herméticas y se conservó a $-4{ }^{\circ} \mathrm{C}$ en un refrigerador antes de utilizar.

Composición proximal y perfil de aminoácidos en las dietas. El análisis de la composición proximal incluye materia seca, proteína cruda, ceniza, fibra cruda, extracto etéreo y extracto libre de nitrógeno se determinó de acuerdo con AOAC (2019). La energía bruta de las dietas se calculó con base en factores de conversión de 16,7 kJ.g-1 de proteína y carbohidratos y 37,6 kJ.g ${ }^{-1}$ de lípidos (Cuzon y Guillaume, 1997; NRC, 2011). Los perfiles de aminoácidos también se elaboraron por triplicado después de que las dietas se liofilizaron y desgrasaron. Estas muestras se analizaron mediante cromatografía líquida de alta resolución (Agilent 1100 - HPLC, Pleasanton, CA) 
Rev. Fac. Agron. (LUZ). 2021, 38: 84-104. Enero-Marzo.

Méndez-Martínez et al.

Food Efficiency $(\mathrm{FE})=$ total weight gain (g, wet weight)/ total feed consumed (g, dry weight).

Survival rate $(\mathrm{SR}, \%)=$ (final number of fishes / initial number of fishes) $\times 100$.

Where $W x$ is the final body weight (g), Wi is the initial body weight (g), and $t$ is the duration of the experiment (days), $L x$ is the final body length (cm), $L i$ is the initial body length $(\mathrm{cm}) . W d$ is the weight of diet consumed by the fish.

Statistical analysis: KolmogorovSmirnov $(\mathrm{p}<0.05)$ and Bartlett $(\mathrm{p}<$ 0.05 ) tests were applied to the data to determine normality and homogeneity of variance, respectively. A one-way ANOVA was applied and subsequently the Duncan's test for $\mathrm{p}<0.05$, using SPSS v-22.0. Data expressed in percentages were transformed by the square root of the arcsine before statistical analysis.

\section{Results and discussion}

The African catfish, a major species for human consumption in many African countries, exhibits high growth performances and important capacities to grow on various rearing conditions. In general, water quality parameters of temperature $\left(27.05^{\circ} \mathrm{C}\right)$, dissolved oxygen (5.64 mg. $\left.\mathrm{L}^{-1}\right), \mathrm{pH}$ (8.04) and total ammonium (0.06) were maintained as recommended for this species (Dada and Olugbemi, 2013; Admassu et al., 2015), and diets were formulas with ingredients, similar to those used in other research (Sogbesan et al., 2006; Adebola et al., 2015).
Evaluación de tasas de crecimiento y producción. Los peces se pesaron individualmente en una balanza digital $( \pm 0,01 \mathrm{~g}$; PE 3600 Mettler-Toledo, Columbus, OH, EE. UU.), Y la longitud total se determinó con un vernier digital $( \pm 0,001 \mathrm{~mm}$, GT-MA15 Gester, Xiamen, CHN). Todos los cálculos se obtuvieron de un promedio de cuatro repeticiones. Se aplicaron las siguientes fórmulas para obtener parámetros productivos y nutricionales.

Aumento de peso (WG, g) $=W x-W i$,

Ganancia de longitud (LG, g) $\mathrm{LG}=L x-L i$,

Aumento de peso promedio diario $\mathrm{DAW}=(W x-W i) / t$,

Aumento de longitud promedio diaria DAL $=(L x-L i) / t$,

Tasa de crecimiento específico $(\mathrm{SGR})=[(\ln W x-\ln W i)] / t \times 100$,

Relación de conversión de alimento $(\mathrm{FCR})=$ alimento total consumido (g) / ganancia de peso total (g, peso húmedo),

Eficiencia alimentaria (FE) = aumento de peso total (g, peso húmedo) I alimento total consumido (g, peso seco).

Tasa de supervivencia (SR, \%) = (número final de peces / número inicial de peces) $\times 100$.

Donde $W x$ es el peso corporal final (g), Wi es el peso corporal inicial (g) y t es la duración del experimento (días), $L x$ es la longitud corporal final (cm), $L i$ es la longitud corporal inicial (cm). $W d$ es el peso de la dieta consumida por el pez.

Análisis estadístico: Se aplicaron las pruebas de Kolmogorov-Smirnov $(\mathrm{p}<0,05)$ y Bartlett $(\mathrm{p}<0,05)$ a los 
Rev. Fac. Agron. (LUZ). 2021, 38: 84-104. Enero-Marzo.

The chemical composition of duckweed meal grown in open systems reflected high level of protein and low fiber (table 2). The percentage of dry matter in the case of meal is considered adequate, as is calcium and phosphorus, since it is a plant material. The values obtained confirms what was reported by Leng et al. (1995) and Korkut et al. (2016), these researchers showed that plants of this genus, because of their ability to grow up rapidly and produce proteinrich biomasses, they can be used as food for farm animals, especially for fish. Duckweeds are tiny free-floating monocotyledon vascular plants constitute an important nutrient potential in the diets of aquaculture species, although it presents dry matter values between 5 and $6 \%$ (Islami, 2002; Appenroth et al., 2017). On the other hand, Anderson et al. (2011) and Appenroth et al. (2017), refers that the form of presentation of the Lemna in meal, improvement nutrients concentration, especially the content of essential amino acids. It should also be noted that there were favorable ecological conditions in the production of the duckweed and that due to the great capacity of these plants they could influence the chemical composition.

The crude protein in L. perpusilla $(27.59 \%)$, could substitute the vegetable protein sources from diets, taking into account that this element is a decisive nutrient in the live weight gain of fish. These results coincide with those of other authors dedicated to the study of the plants of the genus Lemna (Korkuk et al., 2016). According to Yeo datos para determinar la normalidad y homogeneidad de la varianza, respectivamente. Se aplicó un ANOVA de una vía y posteriormente la prueba de Duncan para $\mathrm{p}<0,05$, utilizando SPSS v-22.0. Los datos expresados en porcentajes fueron transformados por la raíz cuadrada del arcoseno antes del análisis estadístico.

\section{Resultados y discusión}

El bagre africano, una especie importante para el consumo humano en muchos países africanos, exhibe un alto rendimiento en crecimiento e importantes capacidades para crecer en diversas condiciones de cría. En general, los parámetros de calidad del agua, como la temperatura $(27,05$ ${ }^{\circ} \mathrm{C}$ ), oxígeno disuelto (5,64 mg.L $\left.\mathrm{L}^{-1}\right)$, $\mathrm{pH}(8,04)$ y amonio total $(0,06)$ se mantuvieron dentro de los valores recomendados para esta especie (Dada y Olugbemi, 2013; Admassu et al., 2015), y las dietas eran fórmulas con ingredientes, similares a los utilizados en otras investigaciones (Sogbesan et al., 2006; Adebola et al., 2015).

La composición química de la harina de lenteja de agua cultivada en sistemas abiertos refleja un alto nivel de proteína y bajo contenido de fibra (cuadro 2). El porcentaje de materia seca en el caso de la harina se considera adecuado, al igual que el calcio y el fósforo, ya que es un material vegetal. Los valores obtenidos confirman lo reportado por Leng et al. (1995) y Korkut et al. (2016), estos investigadores demostraron que las plantas de este género, por su capacidad para crecer rápidamente y 
Rev. Fac. Agron. (LUZ). 2021, 38: 84-104. Enero-Marzo.

Méndez-Martínez et al.

et al., (2017), for the simplicity of the gastrointestinal tract of the fish, the digestibility of the fiber is very low, less than $10 \%$. It serves as a source of volume and as a binder, which is why the characterization of the fiber can determine the nutritional value of fish feed, which confirms the value of the results of this work. If the diet is rich in cellulose, the chyme moves through the digestive tract faster, than when the diet contains less of this nutrient, which is associated with a greater volume of fecal matter. producir biomasas ricas en proteínas, se pueden utilizar como alimento para animales de granja, especialmente para peces. La lenteja de agua está compuesta por diminutas plantas vasculares monocotiledóneas que flotan libremente y constituyen un importante potencial nutritivo en la dieta de las especies acuícolas, aunque presenta valores de materia seca entre el 5 y el 6\% (Islami, 2002; Appenroth et al., 2017). Por otro lado, Anderson et al. (2011) y Appenroth et al. (2017), refieren que la forma

\section{Table 2. Proximate composition of Lemna perpusilla meal (\% in dry matter).}

\section{Cuadro 2. Composición proximal de la harina de Lemna perpusilla (\% en materia seca).}

\begin{tabular}{lcc}
\hline Elements \% & $\mathbf{X}^{1}$ & DE \\
\hline Dry material & 92.31 & 0.18 \\
Crude protein & 27.59 & 0.25 \\
Ethereal extract & 2.08 & 0.10 \\
Crude fiber & 7.22 & 0.22 \\
Ash & 22.60 & 0.47 \\
Nitrogen Free Extract ${ }^{2}$ & 32.83 & 0.13 \\
Phosphorus (P) & 0.53 & 0.40 \\
Calcium (Ca) & 4.50 & 0.14 \\
\hline
\end{tabular}

${ }^{1}$ Data are expressed as mean \pm SD of three replicates. ${ }^{2}$ Nitrogen free extract $=100-(\%$ crude protein $+\%$ ether extract $+\%$ crude fiber $+\%$ ash).

${ }^{1}$ Los datos se expresan como media \pm DE de tres réplicas. ${ }^{2}$ Extracto libre de nitrógeno $=100$ - $(\%$ proteína bruta $+\%$ extracto etéreo $+\%$ fibra bruta $+\%$ ceniza).

These results are lower than those reported by Figueroa (1996), the level of fiber in food can also be referred to the age of the plant, where the older ones have higher content of lignocellulosic complex, which decreases the digestibility of the food. It is demonstrated by analyzing the de presentación de la Lemna en la comida, mejora la concentración de nutrientes, especialmente el contenido de aminoácidos esenciales. Cabe señalar también que existieron condiciones ecológicas favorables en la producción de la lenteja de agua y que debido a la gran capacidad de 
chemical composition of Lemna species that can be used in the supplementary feeding of aquaculture species such as C. gariepinus, with high availability and at lower cost than with the use of commercial feed, coinciding with Korkuk et al. (2016).

The food sources used for the cultivation of $C$. gariepinus in African and Asian countries are very broad (Admasu et al., 2015) and sometimes include the use of aquatic weeds, which gives importance to what is investigated in this work. Diets formulated they have a high percentage of protein, superior to those shown in other investigations for this stage (Llanes and Toledo, 2016), which could have an influence on the final weight. However, significant differences were observed in the control treatment with the percentages of inclusion of duckweed meal, except for $12 \%$. Result that could be associated to the stable behavior of the physical-chemical factors studied in close relation to the quality and size of the pellet, which in the framework of this investigation had a diameter of $2-\mathrm{mm}$ and a time of water stability of seven minutes, which justifies the results of this study.

Work developed in other research corroborates what was obtained in this research, as these authors obtained higher growth rates in the diets that showed the highest protein content (Ogunji and Wirth, 2001; Dada et al., 2013; Adebola et al., 2015; Méndez et al., 2018). Something similar happened for the length and weight gain. The average daily gain showed the best results for balanced estas plantas podrían influir en la composición química.

La proteína cruda de L. perpusilla $(27,59 \%)$, podría sustituir a las fuentes de proteínas vegetales de las dietas, teniendo en cuenta que este elemento es un nutriente decisivo en la ganancia de peso vivo de los peces. Estos resultados coinciden con los de otros autores dedicados al estudio de las plantas del género Lemna (Korkuk et al., 2016). Según Yeo et al. (2017), por la sencillez del tracto gastrointestinal de los peces, la digestibilidad de la fibra es muy baja, menos del $10 \%$. Sirve como fuente de volumen y como aglutinante, por lo que la caracterización de la fibra puede determinar el valor nutricional del pienso para peces, lo que confirma el valor de los resultados de este trabajo. Si la dieta es rica en celulosa, el quimo se mueve por el tracto digestivo más rápido que cuando la dieta contiene menos de este nutriente, lo que se asocia con un mayor volumen de materia fecal.

Estos resultados son inferiores a los reportados por Figueroa (1996), el nivel de fibra en los alimentos también puede referirse a la edad de la planta, donde las más viejas tienen mayor contenido de complejo lignocelulósico, lo que disminuye la digestibilidad del alimento. Se demuestra al analizar la composición química de especies de Lemna que pueden ser utilizadas en la alimentación complementaria de especies acuícolas como $C$. gariepinus, con alta disponibilidad y a menor costo que con el uso de piensos comerciales, coincidiendo con Korkuk et al. (2016).

Las fuentes alimentarias utilizadas 
Rev. Fac. Agron. (LUZ). 2021, 38: 84-104. Enero-Marzo.

Méndez-Martínez et al.

feed, although without differences with the diet where $12 \%$ of the Lemna meal was included. In investigations developed by Uddin et al. (2007), used fish silage, with the use of this plant and obtained the average values

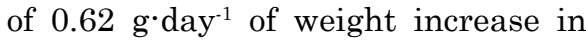
different experimental diets, similar to those obtained for the first level of inclusion.

It is necessary to emphasize that the balance of amino acids and essential fatty acids, in which omega 3 and its high digestibility are included, low levels of antinutritional factors and unidentified growth factors influenced the results of this research, which coincides with the notified by Zhou et al. (2004). It also corroborates what other authors have said when referring that these species in fingerling stages require high level of proteins (Mambrini and Guillaume, 2011). The average daily gain of size showed the best results for the first three established diets, without differences between them, which could be given by the composition and the contributions of nutrients and the chemical composition of duckweed (Anderson et al., 2011).

The highest final body length, LG, DAL, FCR and FE were significant $(p<0.05)$ observed in African catfish fingerlings fed the L. perpusilla meal content on 0,6 and $12 \%$ of diet (table $3)$. The catfish fingerlings fed the $L$. perpusilla meal content at 0 and $12 \%$ of diet exhibited statistically significant $(p<0.05)$ improve in final body weight, WG, DAW and Feed consumption than those fed other diets. With respect to SGR the highest values were observed para el cultivo de C. gariepinus en países africanos y asiáticos son muy amplias (Admasu et al., 2015) y en ocasiones incluyen el uso de malezas acuáticas, lo que da importancia a lo que se investiga en este trabajo. Las dietas formuladas tienen un alto porcentaje de proteína, superior a los mostrados en otras investigaciones para esta etapa (Llanes y Toledo, 2016), lo que podría influir en el peso final. Sin embargo, se observaron diferencias significativas en el tratamiento control con los porcentajes de inclusión de harina de lenteja de agua, excepto para el $12 \%$ de inclusión. Resultado que podría estar asociado al comportamiento estable de los factores físico-químicos estudiados en estrecha relación con la calidad y tamaño del pellet, que en el marco de esta investigación tuvo un diámetro de $2 \mathrm{~mm}$ y un tiempo de estabilidad al agua de siete minutos, lo que justifica los resultados de este estudio.

El trabajo desarrollado en otras investigaciones corrobora lo obtenido en esta investigación, ya que estos autores obtuvieron mayores tasas de crecimiento en las dietas que mostraron mayor contenido proteico (Ogunji y Wirth, 2001; Dada et al., 2013; Adebola et al., 2015; Méndez et al., 2018). Algo similar sucedió con la longitud y el aumento de peso. La ganancia diaria promedio mostró los mejores resultados para la alimentación balanceada, aunque sin diferencias con la dieta donde se incluyó el $12 \%$ de la harina de Lemna. En investigaciones desarrolladas por Uddin et al. (2007), utilizaron ensilaje de pescado, con el uso de esta 
Rev. Fac. Agron. (LUZ). 2021, 38: 84-104. Enero-Marzo.

Méndez-Martínez et al.

ISSN 2477-9407

in fingerlings fed the diets containing duckweed meal content on $0 \%$ of diet. planta y obtuvieron valores promedio de $0,62 \mathrm{~g} \cdot$ día $^{-1}$ de aumento de peso

\section{Table 3. Productive responses ( \pm EE) of Clarias gariepinus fingerlings fed diets containing different Lemna perpusilla meal content.}

\section{Cuadro 3. Respuestas productivas ( \pm EE) de alevines de Clarias gariepinus alimentados con dietas con diferentes contenidos de harina de Lemna perpusilla.}

\begin{tabular}{|c|c|c|c|c|c|}
\hline \multirow{2}{*}{$\begin{array}{l}\text { Productive } \\
\text { responses }\end{array}$} & \multicolumn{4}{|c|}{ Lemna perpusilla meal content (\%) } & \multirow{2}{*}{$\mathbf{P}$} \\
\hline & $\mathbf{0}$ & 6 & 12 & 18 & \\
\hline Final weight (g) & $35.33 \pm 0.73^{\mathrm{c}}$ & $28.31 \pm 0.64^{\mathrm{ab}}$ & $30.48 \pm 1.65^{\mathrm{bc}}$ & $25.07 \pm 1.18^{\mathrm{a}}$ & 0.007 \\
\hline Final length (cm) & $15.65 \pm 0.21^{b}$ & $14.28 \pm 0.23^{\mathrm{ab}}$ & $15.40 \pm 0.28^{b}$ & $13.58 \pm 0.35^{\mathrm{a}}$ & 0.048 \\
\hline Weight Gain (g) & $33.96 \pm 0.68^{c}$ & $27.04 \pm 0.60^{\mathrm{ab}}$ & $29.15 \pm 1.21^{\mathrm{bc}}$ & $23.70 \pm 1.30^{\mathrm{a}}$ & 0.008 \\
\hline $\begin{array}{l}\text { Day average weight } \\
\text { gain }\left(\text { g.day }^{-1}\right)\end{array}$ & $0.72 \pm 0.01^{\mathrm{c}}$ & $0.58 \pm 0.02^{\mathrm{ab}}$ & $0.62 \pm 0.10^{\mathrm{bc}}$ & $0.50 \pm 0.02^{\mathrm{a}}$ & 0.008 \\
\hline Length gain $(\mathrm{cm})$ & $10.38 \pm 0.38^{\mathrm{b}}$ & $9.15 \pm 0.45^{\mathrm{ab}}$ & $10.32 \pm 0.29^{b}$ & $8.33 \pm 0.32^{\mathrm{a}}$ & 0.045 \\
\hline $\begin{array}{l}\text { Day average length } \\
\text { gain }\left(\mathrm{cm}^{\text {day }}{ }^{-1}\right)\end{array}$ & $0.22 \pm 0.02^{b}$ & $0.19 \pm 0.02^{\mathrm{ab}}$ & $0.22 \pm 0.03^{b}$ & $0.18 \pm 0.01^{\mathrm{a}}$ & 0.045 \\
\hline Specific growth rate & $6.90 \pm 0.08^{\mathrm{c}}$ & $6.60 \pm 0.12^{\mathrm{b}}$ & $6.66 \pm 0.09^{b}$ & $6.17 \pm 0.07^{\mathrm{a}}$ & 0.040 \\
\hline $\begin{array}{l}\text { Average feed } \\
\text { consumption (g) }\end{array}$ & $38.90 \pm 0.90^{\mathrm{d}}$ & $32.07 \pm 089^{\mathrm{b}}$ & $34.29 \pm 1.34^{\mathrm{cd}}$ & $29.78 \pm 0.98^{a}$ & 0.001 \\
\hline Feed conversion ratio & $1.15 \pm 0.05^{\mathrm{a}}$ & $1.20 \pm 007^{\mathrm{a}}$ & $1.19 \pm 0.03^{\mathrm{a}}$ & $1.31 \pm 0.08^{\mathrm{a}}$ & 0.744 \\
\hline Feed Efficiency & $0.88 \pm 0.04^{\mathrm{a}}$ & $0.85 \pm 0.08^{\mathrm{a}}$ & $0.85 \pm 0.04^{\mathrm{a}}$ & $0.80 \pm 0.08^{\mathrm{a}}$ & 0.845 \\
\hline
\end{tabular}

a,b,c,d Different letters within the same row, differ significantly for $\mathrm{p}<0.05 .{ }^{1}$ Data are expressed as mean \pm EE.

a,b,c,d Letras diferentes dentro de la misma fila, difieren significativamente para $p<0,05$. 1Los datos se expresan como media $\pm \mathrm{EE}$.

However, in the growth rate the best result was reflected in the control treatment, where the antinutritional factors and percentage fiber on diet could have an influence. Fiber levels increased in the diet as levels of Lemna meal increased. Van-Weerd et al. (2000), using soya meal, as a substitute for fishmeal, with levels of $18 ; 41$ and $69 \%$ of inclusion in the diet of $C$. gariepinus showed a depression en diferentes dietas experimentales, similares a los obtenidos para el primer nivel de inclusión.

Es necesario resaltar que el balance de aminoácidos y ácidos grasos esenciales, en los que se incluyen los omega 3 y su alta digestibilidad, bajos niveles de factores antinutricionales y factores de crecimiento no identificados influyeron en los resultados de esta investigación, que 
in the growth of this species, by increasing the levels of soya meal, which justifies the results obtained in this work. In other studies, conducted by Ogunji and Wirth (2001) used blood meal replacing fish meal in isoprotein feeds with $37.0 \%$ protein for tilapia fish nutrition and obtained a higher FCR, related to the composition of the granulates and higher feed rates. In the alimentary efficiency there were no significant differences between the diets studied, something similar happened with the FCR, which was below 1.7. The difference between the treatments in this aspect is given by the animals ingesting similar amounts of dry matter. Similar results were obtained by Méndez et al. (2018) who studied similar inclusion percentages of the Azolla plant in the genus Claria.

Fingerlings of red tilapia (Orechromis spp.) were fed with different levels of Lemna meal inclusion and were reached FCA values (2.04 to 2.52) (Peters et al., 2009), were obtained that differed from those obtained in this experiment, which shows a better use of food by the African catfish fingerlings. Is important to point out that food efficiency is directly linked to the FCR, so for a higher efficiency there must be a lower conversion factor.

The survival rates reached in this study were relatively high (figure 1), for this stage of fingerling and type of crop (super-intensive). The polynomial regression analysis between survival and dietary duckweed meal content was $\mathrm{y}=-1.375 \mathrm{x}^{2}+4.785 \mathrm{x}+67.775$ $\left(\mathrm{R}^{2}=0.9851\right)$, It was found that the higher minute duckweed meal content coincide con lo notificado por Zhou et al. (2004). También corrobora lo dicho por otros autores al referirse a que estas especies en estadios de alevines requieren alto nivel de proteínas (Mambrini y Guillaume, 2011). La ganancia de tamaño promedio diaria mostró los mejores resultados para las tres primeras dietas establecidas, sin diferencias entre ellas, lo que podría estar dado por la composición y los aportes de nutrientes y la composición química de la lenteja de agua (Anderson et al., 2011).

La longitud corporal final más alta, LG, DAL, FCR y FE fueron significativas $(p<0,05)$ observadas en alevines de bagre africano alimentados con el contenido de harina de $L$. perpusilla con 0,6 y 12 $\%$ de la dieta (cuadro 3). Los alevines de bagre alimentados con el contenido de harina de $L$. perpusilla al 0 y 12 $\%$ de la dieta exhibieron una mejora estadísticamente significativa ( $p$ $<0,05)$ en el peso corporal final, WG, DAW y consumo de alimento que aquellos alimentados con otras dietas. Con respecto a la SGR, los valores más altos se observaron en los alevines alimentados con dietas con contenido de harina de lenteja de agua al $0 \%$ de la dieta

Sin embargo, en la tasa de crecimiento el mejor resultado se reflejó en el tratamiento control, donde los factores antinutricionales y el porcentaje de fibra en la dieta pudieron influir. Los niveles de fibra aumentaron en la dieta a medida que aumentaron los niveles de harina de Lemna. Van-Weerd et al. (2000), utilizando harina de soja, como 
Rev. Fac. Agron. (LUZ). 2021, 38: 84-104. Enero-Marzo.

Méndez-Martínez et al.

the survival decreases. In all the variables evaluated, the lowest values were significantly $(p<0.05)$ obtained with the treatment where the Lemna perpusilla meal content on $18 \%$ diet. sustituto de la harina de pescado, con niveles de 18; 41 y 69 \% de inclusión en la dieta de $C$. gariepinus mostró una depresión en el crecimiento de esta especie al aumentar los niveles

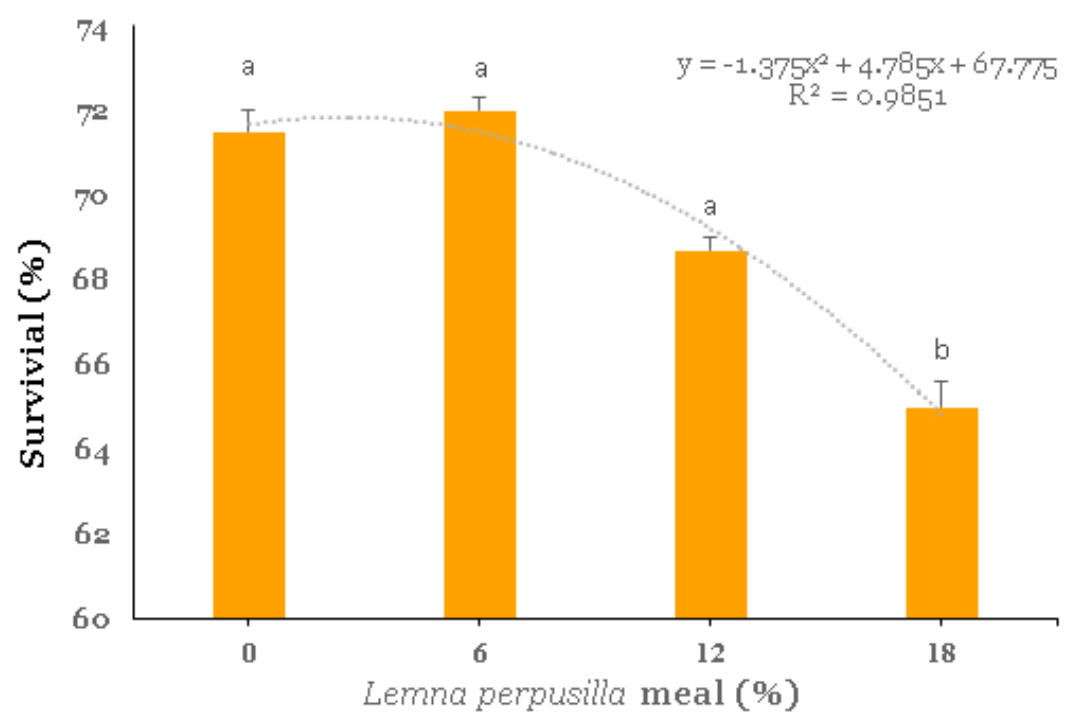

Figure 1. Survival of Clarias gariepinus fingerlings fed diets containing different Lemna perpusilla meal content.

Figura 1. Supervivencia de alevines de Clarias gariepinus alimentados con dietas con diferentes contenidos de harina de Lemna perpusilla.

For survival there were differences between the treatments, the percentages are between 65 and 72 , this was due to the stress that fish raised in captivity can have. These results are similar to those obtained by different authors in other fish species such as Scophthalmus maximus (Van-Weerd et al., 2000; Sogbesan et al., 2006; Méndez et al., 2018). The established according to (Coche, 1989) is between de harina de soja, lo que justifica los resultados obtenidos en este trabajo. En otros estudios, realizados por Ogunji y Wirth (2001), se utilizó harina de sangre que reemplazó la harina de pescado en alimentos con isoproteicos con $37,0 \%$ de proteína para la nutrición de peces de tilapia y obtuvieron una FCR más alta, relacionada con la composición de los granulados y tasas de alimentación 
Rev. Fac. Agron. (LUZ). 2021, 38: 84-104. Enero-Marzo.

Méndez-Martínez et al.

$30-40 \%$, results at productive scale and not at experimental level where the predation was controlled with the homogenization of the sizes and the weight, besides an adequate management of the African catfish fingerlings (C. gariepinus) throughout the bioassay, avoiding stress among the fingerlings. However, the work of Llanes and Toledo (2016), showed survival of over $95 \%$ in this species when fed diets with an increase in dietary protein, which influenced the results obtained, and demonstrates the potential of the species, besides the conditions of established management.

\section{Conclusion}

The meal of $L$. perpusilla is characterized by having high levels of proteins and low crude fiber, making possible its use in the diet of the second stage of African catfish fingerlings $(C$. gariepinus), this study demonstrated that raw $L$. perpusilla can be utilized up to $12 \%$ inclusion level in the ration without affecting the productive results.

\section{End of English Version}

más altas. En la eficiencia alimentaria no hubo diferencias significativas entre las dietas estudiadas, algo similar sucedió con la FCR, que estuvo por debajo de 1,7. La diferencia entre los tratamientos en este aspecto viene dada por los animales que ingieren cantidades similares de materia seca. Méndez et al. (2018) obtuvieron resultados similares, quienes estudiaron porcentajes de inclusión similares de la planta Azolla en el género Claria.

Se alimentaron alevines de tilapia roja (Orechromis spp.) Con diferentes niveles de inclusión de harina de Lemna y se alcanzaron valores de FCA (2,04 a 2,52) (Peters et al., 2009), que difirieron de los obtenidos en este experimento, lo que muestra un mejor aprovechamiento de los alimentos por parte de los alevines de bagre africano. Es importante señalar que la eficiencia alimentaria está directamente ligada al FCR, por lo que para una mayor eficiencia debe existir un factor de conversión menor.

Las tasas de supervivencia alcanzadas en este estudio fueron relativamente altas (figura 1), para esta etapa de alevines y tipo de cultivo (superintensivo). El análisis de regresión polinomial entre la supervivencia y el contenido de harina de lenteja de agua en la dieta fue $\mathrm{y}=-1.375 \mathrm{x}^{2}+4.785 \mathrm{x}+67.775\left(\mathrm{R}^{2}\right.$ $=0,9851)$. Se encontró que, a mayor contenido de harina de lenteja de agua, la supervivencia disminuye. En todas las variables evaluadas, los valores significativamente ( $p$ $<0,05$ ) más bajos se obtuvieron con el tratamiento donde el contenido de harina de Lemna perpusilla en la dieta fue del $18 \%$.

Para la supervivencia hubo diferencias entre los tratamientos, los porcentajes están entre 65 y 72 , esto se debe al estrés que pueden tener los peces criados en cautiverio. Estos resultados son similares a los obtenidos por diferentes autores en otras especies de peces como 
Scophthalmus maximus (Van-Weerd et al., 2000; Sogbesan et al., 2006; Méndez et al., 2018). El establecido según POT (2015) está entre 30 - 40 $\%$, resultados a escala productiva y no a nivel experimental donde se controló la depredación con la homogeneización de las tallas y el peso, además de un adecuado manejo de los alevines de bagre africano (C. gariepinus) durante todo el bioensayo, evitando el estrés entre los alevines. Sin embargo, el trabajo de Llanes y Toledo (2016), mostró una supervivencia superior al $95 \%$ en esta especie al ser alimentada con dietas con aumento de proteína en la dieta, lo que influyó en los resultados obtenidos, y demuestra el potencial de la especie, además de las condiciones de manejo establecidas.

\section{Conclusión}

La harina de $L$. perpusilla se caracteriza por tener altos niveles de proteínas y bajo contenido de fibra cruda, posibilitando su uso en la dieta de la segunda etapa de alevines de bagre africano ( $C$. gariepinus), este estudio demostró que $L$. perpusilla cruda puede ser utilizada hasta el 12 $\%$ de nivel de inclusión en la ración sin afectar los resultados productivos.

\section{Literatura citada}

Adebola, A.O., A. Funmilola and F. R. Olorunleke. 2015. Nutrient utilization and growth of Clarias gariepinus fed four different commercial feeds. Int. J. Fish. Aquac. 7(7): 107-110.

Admassu, D., L. Abera and Z. Tadesse. 2015. The food and feeding habits of the African catfish, Clarias gariepinus
(Burchell), in Lake Babogaya, Ethiopia. GJFS. 3(4):211-220.

Anderson, K. E., Z. Lowman, A. M. Stomp and J. Chang. 2011. Duckweed as a feed ingredient in laying hen diets and its effect on egg production and composition. Int. J. Poultry Sci. 10 (1): 4-7.

Ansal, M. D., A. Dhawan and V. I. Kaur. 2010. Duckweed based bioremediation of village ponds: An ecologically and economically viable integrated approach for rural development through aquaculture. Livest. Res. Rural Dev. 22(129): 1-8.

Association of Official Analytical Chemists International (AOAC). 2019. Official Methods of Analysis of AOAC International, 21st Edition. Gaithersburg, Maryland, USA.

Appenroth, K. .J., K. S. Sree, V. Böhm, S. Hammann, W. Vetter, M. Leiterer and G. Jahreis. 2017. Nutritional value of duckweeds (Lemnaceae) as human food. Food Chem. 217: 266-273.

Caicedo, J. R., S. P. Van Der, O. Arce and H. Gijzen. 2000. Effect of total ammonium nitrogen concentration and $\mathrm{pH}$ ongrow thrates of duckweed (Spirodela polyrrhiza). Water Research. 3(2): 12-16.

Cuzon, G. and J. Guillaume. 1997. Energy and protein: energy ratio. p. 51-70. In: D'Abramo, L. R., D. E., Conklin and D.M., Akiyama (Eds.). Crustacean Nutrition. Advances in World Aquaculture, vol. 6. Louisiana State University, Baton Rouge, LA.

da Silva, J. C., E. A. Gubiani and R. L. Delariva. 2014. Use of food resources by small fish species in Neotropical rivers: responses to spatial and temporal variations. Zoologia. 31: 435444.

Dada, A. A. and B. D. Olugbemi. 2013. Dietary effects of two commercial feed additives on growth performance and body composition of African catfish, Clarias gariepinus fingerlings. Afr. J. Food Sci. 7(9): 325-328.

Dadebo, E., D. Aemro, and Y Tekle-Giorgis. 2014. Food and feeding habits of the 
Rev. Fac. Agron. (LUZ). 2021, 38: 84-104. Enero-Marzo.

Méndez-Martínez et al.

ISSN 2477-9407

African catfish Clarias gariepinus (Burchell, 1822) (Pisces: Clariidae) in Lake Koka, Ethiopia. Afr. J. Ecol. 52(4): 471-478.

FAO. 2020. FishStatJa tool for fishery statistics analysis, Release 2.0.0. Universal software for fishery statistical time series. Global capture and aquaculture production: Quantities 1950-2018; Aquaculture values 1984-2018. Food and Agriculture Organization (FAO) Fisheries Department, Fishery Information, Data and Statistics Unit. Rome.

Fasakin, E. A., A. M. Balogun and O. A. Fagbenro. 2001. Evaluation of sundried water fern, Azolla africana and duckweed, Spirodela polyrrhiza in practical diets for nile tilapia, Oreochromis niloticus fingerlings. J. Appl. Aquac. 11(1): 83-92.

Figueroa, V. 1996. Producción porcina con cultivos tropicales y reciclajes de nutrientes. Fundación CIPAV, Cali, Colombia. 155 p.

Flores-Miranda, M. C., A. Luna-González, D. V. Cortés-Espinosa, P. ÁlvarezRuiz, E. Cortés-Jacinto, F. J. ValdezGonzález, R. Escamilla-Montes and H. A. González-Ocampo. 2015. Effects of diets with fermented duckweed (Lemna sp.) on growth performance and gene expression in the Pacific white shrimp, Litopenaeus vannamei. Aquacult Int. 23: 547-561.

Herawati, V. E., Pinandoyo, Y. S. Darmanto, N. Rismaningsih, S. Windarto and O. K. Radjasa. 2020. The effect of fermented duckweed (Lemna minor) in feed on growth and nutritional quality of tilapia (Oreochromis niloticus). Biodiversitas 21(7): 3350-3358.

Houlihan, D., T. Boujard and M Jobling. 2001. Food Intake in Fish. Blackwell Science, Oxford, UK. 143 p.

Islami, K. M. S. 2002. Feasibility of duckweed as poultry feed-A review. Indian J. Anim. Sci. 72(6): 486-491.

Kader, M. A., M. Bulbul, M. S. Hossain, S. Yokoyama, M. Ishikawa and S. Koshio. 2013. Improved utilization of a plant byproducts mixture by supplementing dietary bamboo charcoal for Juvenile Amberjack Seriola dumerili. South Pacific Studie. 34(1): 1-12.

Korkut, A. Y., A. Gunes, A. Kop, H. Cakar, O. Akat, M. A. Guney, B. Ozkul, E. Koru, C. Suzer, S. Cirik, K. Firat, S. Saka and C. Goktepe. 2016. Preliminary study for utilization of some invasiveaquatic plants as raw material for aquaculture feeds. Fresenius Environ. Bull. 25(11): 4915-4920.

Leng, R. A., J. H. Stambolie and R. Bell. 1995. Duckweed a potential high protein feed resource for domestic animal and fish. Livestock Res. Rural Dev. 7(3): 1-5.

Lim, S. J. and K. J. Lee. 2011. A microbial fermentation of soybean and cottonseed meal increases antioxidant activity and gossypol detoxification in diets for nile tilapia, Oreochromis niloticus. J. World Aquacult. Soc. 42(4): 494- 503.

Llanes, J. and J. Toledo. 2016. Desempeño productivo de Clarias gariepinus al reducir la ración e incrementar la proteína dietética. Revista Cubana de Investigaciones Pesqueras. 33(1): 59-63.

Mambrini, M. and J. Guillaume. 2011. Protein nutrition. In: Guillaume, J., S., Kaushik, P., Bergot, and R., Métailler. (Eds.). Nutrition and Feeding on Fish and Crustaceous. Springer and Praxis Publishing, Chichester, UK. p 81-110.

McBride, R. S., S. Somarakis, G. R. Fitzhugh, A. Albert, N. A. Yaragina, M. J. Wuenschel and A. Alonso-Fernández. 2015. Energy acquisition and allocation to egg production in relation to fish reproductive strategies. Fish Fish. 16(1): 23-57.

Méndez, Y., D. Chacón, Y. Pérez y J. Ramírez. 2018. El crecimiento y la supervivencia de alevines de Clarias gariepinus con la inclusión de Azolla en la dieta. REDVET. 19(4): 1-5.

Méndez-Martínez, Y., M. U. García-Guerrero, F. G. Arcos-Ortega, L. R. MartínezCórdova, S. Yamasaki-Granados, J. C. Pérez-Rodríguez and E. Cortés- 
Jacinto. 2018. Effect of different ratios of dietary protein-energy on growth, body proximal composition, digestive enzyme activity, and hepatopancreas histology in Macrobrachium americanum (Bate, 1868) prawn juveniles. Aquaculture. 485: 1-11.

Méndez-Martínez, Y., S. YamasakiGranados, M. U. García-Guerrero, L. R. Martínez-Córdova, M. E. Rivas-Vega, F. G. Arcos-Ortega and E. Cortés-Jacinto. 2017. Effect of dietary protein content on growth rate, survival and body composition of juvenile cauque river prawn, Macrobrachium americanum (Bate 1868). Aquac. Res. 48: 741-751.

Nutrient requirements of fish and shrimp (NRC). 2011. National Research Council, National Academies Press, Animal Nutrition Series, Washington, DC. $71 \mathrm{p}$.

Ogunji, J. O. and M. Wirth. 2001. Alternative protein sources as substitutes for fishmeal in the diet of Young Tilapia Oreochromis niloticus (Linn). Isr. J Aquacult. Bamid. 53(1): 34-38.

Peters, R. R. D., E. D. A. Morales, N. M. S. Morales and J. L. R. Hernández. 2009. Feeding Quality Evaluation of Lemna obscura Meal as Ingredients in the Elaboration of Food for Red Tilapia (Orechromis spp.). Revista Científica, FCV-LUZ. 19(3): 303-310.

Procedimiento Operacional de Trabajo (POT). 2015. Procedimiento Operacional de Trabajo actualizado, para el cultivo intensivo de Pez Gato Africano. Ministerio de la Industria Pesquera. La Habana. Cuba. 39 p.

Coche, A. E. P. 1989. Selected Aspects of of Warmwater Fish Culture. Biology and culture of african catfish. Food and Agriculture Organizations of the United Nations, Rome, Italy. 182 pp. Avalaible in: http://www.fao.org/3/ t8389e/T8389E00.htm

Putra, I., R. Rusliadi, M. Fauzi, U. M. Tang and Z. A. Muchlisin. 2017. Growth performance and feed utilization of African catfish Clarias gariepinus fed a commercial diet and reared in the biofloc system enhanced with probiotic. F1000 Res. 6: 1545-1553.
Sirakov, I. and K. Velichkova. 2018. The Influence of Aquaponically Grown Duckweed (Lemna minuta Kunth) Used for Composition of Sustainable Diets on Hydrochemical and Technological Parameters in Carp (Cyprinus carpio L.). Turkish J. Fish. Aquat. Sci. 18: 1037-1044.

Sogbesan, A. O., N. Ajuonu, B. O. Musa and A. M. Adewole. 2006. Harvesting techniques and evaluation of maggot meal as animal dietary protein source for "Heteroclarias" in outdoor concrete tanks. World J. Agric. Res. 2(4): 394-402.

Talukdar, M. Z. H., M. Shahjahan and M. S. Rahman. 2012. Suitability of duckweed (Lemna minor) as feed for fish in polyculture system. Int. J. Agril Res. Innov. and Tech. 2: 42-46.

Uddin, M. N., M. S. Rahman and M. Shahjahan. 2007. Effects of duckweed (Lemna minor) as supplementary feed on monoculture of GIFT strain of tilapia (Oreochromis niloticus). Progress. Agric. 18: 183-188.

Umagat, H. P Kucera and L. F. Wen. 1982. Total amino acid analysis using precolumn fluorescence derivatization. J. Chromatogr. 239: 463-474.

Van-Weerd, J. H., K. H. A. Khalaf, F. J. Aartsen and P. A. T. Tijssen. 2000. Balance trials with African catfish Clarias gariepinus fed phytasetreated soybean meal-based diets. Aquac. Nutr. 5(2): 135-142.

Yeo, M. G., C. M. Blé, A. K. Otchoumou, S. Dabonne, Y. L. Alla and A. O. Etchian. 2017. Digestibility and growth performance in fingerlings of tilapia Oreochromis niloticus fed with diet containing high-carbohydrate ingredients. Int. J. Fish. Aquat. Studies 5(4): 171-175.

Zhou, Q. C., B. P. Tan, K. S. Mai and Y. J. Liu. 2004. Apparent digestibility of selected feedin gredients for juvenile cobia Rachycentron canadum. Aquaculture 241: 441-451. 